\title{
The development of diabetes mellitus and chronic liver disease in long term chelated $\beta$ thalassaemic patients
}

\author{
V. De Sanctis ${ }^{1}$, G. D'Ascola ${ }^{1}$ and B. Wonke ${ }^{2}$ \\ ${ }^{1}$ Arcispedale S. Anna, Divisione Pediatrica, USL 31, Ferrara, Italy, and ${ }^{2}$ Whittington Hospital, Highgate, London \\ N19 5NF, UK.
}

\begin{abstract}
Summary: We studied 29 patients with thalassaemia major who had received intensive chelation for between 6.2 and 8.8 years. All patients had normal oral glucose tolerance tests before subcutaneous chelation therapy was introduced and 22 of 29 patients had normal liver function tests. At the end of the period of study 12 patients still had normal oral glucose tolerance (7 with normal liver function tests and 5 with chronic active hepatitis). On the other hand, 11 patients had developed impaired glucose tolerance tests ( 3 patients had normal liver function tests, 5 with chronic active hepatitis and 3 with cirrhosis), and 6 patients had developed frank diabetes mellitus (one with chronic active hepatitis and 5 with cirrhosis). Patients with chronic active hepatitis showed $91 \%$ positivity for one or more hepatitis B markers whilst all patients with cirrhosis were positive. Ferritin levels before subcutaneous chelation in patients with normal oral glucose tolerance tests were lower than in those patients with abnormal oral glucose tolerance or diabetes $(P<0.05)$ but none had normal serum ferritin levels. In addition, a positive correlation was found between glucose area under the curve after chelation therapy and serum ferritin levels $(r=0.47$, $P<0.01)$.

It is apparent that long term chelation therapy does not prevent the development of abnormal oral glucose tolerance in chronically transfused patients. More intensive chelation therapy is needed to prevent tissue damage. Chronic liver disease may have an important role to play in the deterioration of glucose tolerance.
\end{abstract}

\section{Introduction}

Impaired glucose tolerance and diabetes mellitus is a frequently observed complication in patients with $\beta$ thalassaemia major (Flynn et al., 1976; McIntosh, 1976; Costin et al., 1977; Saudek et al., 1977; Zuppinger et al., 1979; Dandona et al., 1983). High blood transfusion programmes and regular subcutaneous iron chelation with desferrioxamine mesylate (Desferal) were introduced as optimal treatment to patients with $\beta$ thalassaemia major between 1976-1977. This treatment has improved the prognosis and the general well-being of patients with this disease. However, it is not clear which complications of iron overload are prevented by this intensive chelation therapy.

The aim of the present study was to determine to what extent long term chelation prevents the development of impaired glucose tolerance or diabetes and the influence of chronic liver disease on glucose homeostasis in patients with $\beta$ thalassaemia major.

Correspondence: B. Wonke, M.D., M.R.C.Path. Accepted: 10 April 1986

\section{Patients and methods}

Twenty-nine patients (16 males and 13 females) with $\beta$ thalassaemia major attending the Whittington Hospital (London) and Divisione Pediatrica Arcispedale S. Anna (Ferrara) were chosen to participate in the study. Their mean age at the end of the study was $20 \pm 4$ years (age range 12-27 years).

The patients received blood transfusions so that their overall mean haemoglobin levels were kept between $11-12 \mathrm{~g} / \mathrm{dl}$ and were intensively subcutaneously iron chelated with desferrioxamine for 6.2 to 8.8 years; the serum ferritin levels at the end of followup were at least $50 \%$ less than before subcutaneous chelation treatment. The dose of desferrioxamine initially was $35 \mathrm{mg} / \mathrm{kg}$ body weight which was increased up to $80 \mathrm{mg} / \mathrm{kg}$ body weight in some patients. Treatment was given 5 to 6 nights a week via a subcutaneous pump over an 8 to 12 hour period. Ascorbic acid $100-200 \mathrm{mg} /$ day by mouth was also given. All patients were within $10 \%$ of ideal body weight and had normal glucose tolerance tests before subcutaneous chelation was introduced. Twenty-two patients had normal biochemical liver function tests, 
the remaining 7 had abnormal liver function tests before intensive subcutaneous chelation therapy was introduced. Hepatitis serum B markers were not available at the start of subcutaneous chelation therapy.

To assess glucose metabolism the patients received $1.75 \mathrm{~g} / \mathrm{kg}$ body weight of glucose (maximum dose $75 \mathrm{~g}$ ) after an overnight fast before the introduction of subcutaneous iron chelation and $7.5( \pm 1.3)$ years after this therapy. Sixteen non-obese subjects (mean age $20.6 \pm 5.9$ years, range $12-30$ years) served as controls by having glucose and insulin tolerance tests at the end of the study. Venous blood samples for glucose and insulin determination were obtained at 0 , $30,60,90$ and 120 minutes after oral glucose administration. Blood glucose was determined by the glucose oxidase method. To analyse the glucose data we have reported the values at each sampling time and area (0-120 minutes) under the curves after oral glucose tolerance tests (Cacciari et al., 1975). The criteria of the WHO Expert Committee on Diabetes Mellitus were used for the evaluation of oral glucose tolerance (Editorial, 1980). Plasma immunoreactive insulin was estimated by radioimmunoassay (Hales \& Randle, 1963). All blood samples were collected into glass tubes containing fluoride and lithium heparin and immediately centrifuged. The plasma was separated and kept frozen at $-20^{\circ} \mathrm{C}$ for future analysis.

All insulin samples were performed in duplicate and values were expressed in $\mathrm{mU} / 1$. The insulin response was determined from the peak values and area $(0-120$ minutes) under the curves after oral glucose tolerance tests (Cacciari et al., 1975). A family history of diabetes was recorded for every patient, including family members as far back as to the grandparents.

The sera of all patients were tested for serum total protein, albumin, aspartate transaminase and gamma glutamyl transpeptidase levels using standard methods. Liver function tests were defined as normal if all the above parameters were normal. Needle liver biopsy was performed in 19 patients who for more than 3-6 months had been showing abnormal liver function tests. Chronic active hepatitis was defined histologically if the following features were present: piecemeal necrosis with associated bridging necrosis or multilobular collapse and cirrhosis when there was a loss of normal lobular architecture with nodular regeneration of parenchymal cells separated by fibrous septae.

The extent of iron overload was expressed in siderosis of hepatocytes (grade 1 to 4). Hepatitis B surface antigen, antibodies to hepatitis B surface and core antigens were tested in all patients using solid phase radioimmunoassay.

Serum ferritin concentration before and after chelation therapy was measured by radioimmunoassay (Addison et al., 1972). The results are presented as mean \pm standard deviation and statistical analysis of the results was carried out by the Student's test; $P<0.05$ was regarded as significant. Linear regression analysis was employed for evaluating correlations between parameters.

\section{Results}

\section{Glucose tolerance tests}

After treatment in 12 patients ( 4 males and 8 females) the oral glucose tolerance tests remained normal $(41.3 \%)$. Their mean age was $18.3( \pm 3.6)$ years. Seven of the 12 patients had normal liver function tests (Group A) and 5 had chronic active hepatitis documented with liver biopsies (Group B).

Eleven patients ( 3 males and 8 females) developed impaired oral glucose tolerance tests $(37.9 \%)$. Their mean age was $21.2( \pm 4.4)$ years. Only 3 of the 11 had normal liver function tests (Group A), 5 chronic active hepatitis (Group B) with siderosis in the hepatocytes grade 3-4, and 3 cirrhosis (Group C) with grade 4 siderosis.

Six patients ( 5 males and 1 female) developed overt diabetes requiring insulin treatment $(20.6 \%)$. Their mean age was $21( \pm 3.2)$ years, all 6 had liver dysfunction, one chronic active hepatitis (Group B)

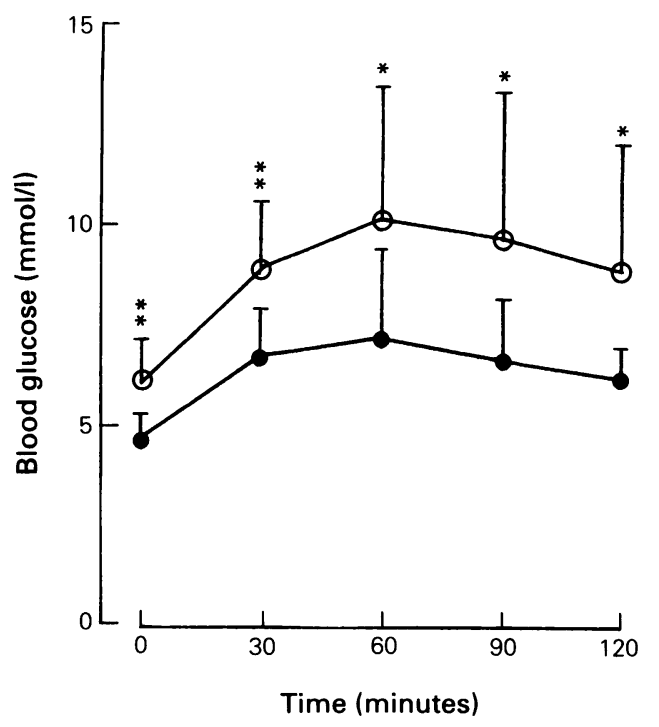

Figure 1 Mean ( \pm s.d.) venous blood concentrations (blood glucose, $\mathrm{mmol} / \mathrm{l}$ ) during oral glucose tolerance test in patients with normal liver function tests $(O)$ and chronic liver diseases (O) after chelation therapy. ${ }^{*} P<0.05 ;{ }^{* *} P<0.01$. 
and 5 cirrhosis (Group C). The results of glucose tolerance tests in patients with normal liver function tests and chronic liver diseases are reported in Figure 1.

The mean age of patients with abnormal glucose tolerance was significantly higher than in patients with normal oral glucose tolerance test $(P<0.05)$. The mean age was also higher in patients with overt diabetes than in patients with normal oral glucose tolerance test; the difference, however, was not statistically significant. A positive family history for diabetes was identical $(41 \%)$ in the patients with normal or abnormal oral glucose tolerance tests.

\section{Serum ferritin concentration}

The mean serum ferritin levels before intensive chelation therapy were $5045( \pm 3352) \mu \mathrm{g} / 1$ in thalassaemic patients with normal oral glucose tolerance tests; 8640 $( \pm 4876) \mu \mathrm{g} / \mathrm{l}$ in patients who subsequently developed impaired oral glucose tolerance tests and 8906 $( \pm 3968) \mu \mathrm{g} / 1$ in patients who subsequently developed diabetes.

The serum ferritin levels were significantly lower in the first than the second and third $(P<0.05)$ groups. After subcutaneous chelation therapy the serum ferritin values were $1320( \pm 1018) \mu \mathrm{g} / \mathrm{l}$ in thalassaemic patients with normal oral glucose tolerance test; 1706
$( \pm 973) \mu \mathrm{g} / \mathrm{l}$ in patients with impaired glucose tolerance tests and $2838( \pm 1556) \mu \mathrm{g} / \mathrm{l}$ in patients with diabetes, the mean serum ferritin of the diabetic patients being significantly higher $(P<0.01)$ than the mean levels of patients with normal glucose tolerance. A positive correlation occurred between glucose area, after chelation therapy, and serum ferritin levels $(r=0.47 ; P<0.01)$, while no demonstrable correlation was found between the glucose area and insulin area before chelation therapy or insulin area, after treatment, and serum ferritin.

\section{Plasma insulin concentrations}

The mean ( \pm s.d.) plasma insulin concentrations, before and after subcutaneous chelation therapy, are shown in Figure 2. After treatment, there were no statistically significant differences between the basal insulin levels in the thalassaemic patients with normal liver function and normal oral glucose tolerance tests and the control group (Table I).

After a glucose load, however, peak values and insulin areas were significantly lower in thalassaemic patients with normal liver function compared with the 16 normal controls $(P<0.05$ and $P<0.01$, respectively). Thalassaemic patients with normal liver function but abnormal oral glucose tolerance tests showed significantly higher basal insulin concentrations than

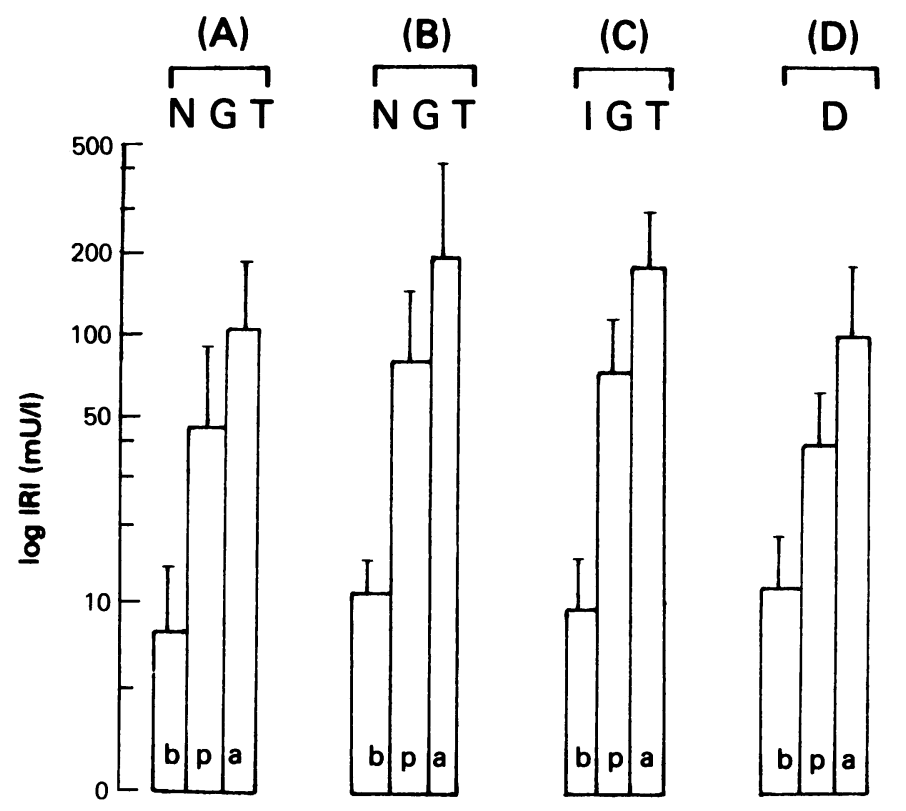

Figure 2 Mean ( \pm s.d.) plasma insulin concentrations (IRI, $\mathrm{mU} / \mathrm{l}$ ) during oral glucose tolerance test before (A) and after (B, C, D) chelation therapy. NGT = normal glucose tolerance; IGT = impaired glucose tolerance; $\mathrm{D}=$ diabetes; $\mathrm{b}=$ basal; $\mathrm{p}=$ peak; $\mathrm{a}=$ area. ${ }^{*} P<0.05$, compared with group $\mathrm{A}$. 
Table I Results of insulin, $\mathrm{mU} / \mathrm{l}$ (basal-peak and area) during oral glucose tolerance test in the thalassaemic patients (Groups $A, B, C)$ and in the control group.

\begin{tabular}{|c|c|c|c|c|}
\hline Group & $\begin{array}{l}\text { Patients with } \\
\text { normal oral glucose } \\
\text { tolerance test }\end{array}$ & $\begin{array}{c}\text { Patients with } \\
\text { impaired oral } \\
\text { glucose tolerance } \\
\text { test }\end{array}$ & $\begin{array}{c}\text { Patients } \\
\text { with diabetes }\end{array}$ & Controls \\
\hline $\begin{array}{l}\text { A Normal liver function } \\
\text { Basal insulin } \\
\text { Peak insulin } \\
\text { Insulin area }\end{array}$ & $\begin{array}{l}\quad(n=7) \\
5.25 \pm 2.6 \\
39.2 \pm 16.0^{*} \\
94.9 \pm 37.5^{* *}\end{array}$ & $\begin{array}{c}(n=3) \\
14.0 \pm 7.6^{* *} \\
71.3 \pm 14.7 \\
173.0 \pm 81.4\end{array}$ & & $\begin{array}{c}(n=16) \\
6.2 \pm 3.5 \\
54.5 \pm 16.5 \\
140.0 \pm 39.8\end{array}$ \\
\hline $\begin{array}{l}\text { B Chronic active hepatitis } \\
\text { Basal insulin } \\
\text { Peak insulin } \\
\text { Insulin area }\end{array}$ & $\begin{array}{l}\quad(n=5) \\
15.2 \pm 7.0^{* * *} \\
136.8 \pm 65.9^{* * *} \\
336.9 \pm 201.4^{* * *}\end{array}$ & $\begin{array}{l}(n=5) \\
10.2 \pm 4.0^{*} \\
87.2 \pm 60.5^{*} \\
214.8 \pm 141.4^{*}\end{array}$ & $\begin{array}{c}(n=1) \\
5.8 \\
35.0 \\
103.0\end{array}$ & \\
\hline $\begin{array}{l}\text { C Cirrhosis } \\
\text { Basal insulin } \\
\text { Peak insulin } \\
\text { Insulin area }\end{array}$ & & $\begin{array}{c}(n=3) \\
10.5 \pm 2.1^{*} \\
51.0 \pm 15.8 \\
142.3 \pm 48.0\end{array}$ & $\begin{array}{c}(n=5) \\
13.3 \pm 6.5^{* *} \\
42.0 \pm 25.9 \\
126.0 \pm 74.2\end{array}$ & \\
\hline
\end{tabular}

Insulin values are expressed in $\mathrm{mU} / 1 ; n=$ number of patients. ${ }^{*} P<0.05 ;{ }^{* *} P<0.01 ;{ }^{* * *} P<0.001$ (compared with controls).

the control group $(P<0.01)$ but there were no statistical differences in peak insulin levels and insulin areas between the two groups. Basal, peak and insulin area were significantly higher in thalassaemic patients with chronic active hepatitis than in controls irrespective of the oral glucose tolerance test result $(P<0.001$ and $P<0.05$, respectively). One patient with chronic active hepatitis and diabetes presented normal basal, peak and insulin area values.

Basal plasma insulin levels were higher in thalassaemic patients with cirrhosis and abnormal oral glucose tolerance tests or frank diabetes than in the controls $(P<0.05)$. However, after a glucose load, the peak and insulin areas were not significantly different from the controls (Table I).

\section{Liver function}

Table II shows the main laboratory liver function tests in the three groups of patients $(\mathrm{A}, \mathrm{B}$ and $\mathrm{C})$. Of the 10 patients with normal liver function, $40 \%$ had positive serum markers for hepatitis B virus. Patients with chronic active hepatitis on liver biopsy showed $91 \%$ positivity for the virus whilst all patients with cirrhosis were positive for one or more hepatitis B markers.

Table II Liver function tests, after subcutaneous chelation therapy in 29 thalassaemic patients

\begin{tabular}{|c|c|c|c|}
\hline & $\begin{array}{l}\text { Group } A \\
\text { Normal liver } \\
\text { function }\end{array}$ & $\begin{array}{c}\text { Group B } \\
\text { Chronic active } \\
\text { hepatitis }\end{array}$ & $\begin{array}{l}\text { Group C } \\
\text { Cirrhosis }\end{array}$ \\
\hline $\begin{array}{l}\text { Serum total protein } \\
\quad(65-80 \mathrm{~g} / 1)\end{array}$ & $\begin{array}{c}(n=10) \\
72.0 \pm 5.3\end{array}$ & $\begin{array}{c}(n=11) \\
72.5 \pm 5.4\end{array}$ & $\begin{array}{c}(n=8) \\
75.0 \pm 6.9\end{array}$ \\
\hline $\begin{array}{l}\text { Serum albumin } \\
\quad(36-52 \mathrm{~g} / \mathrm{l})\end{array}$ & $45.4 \pm 2.0$ & $40.7 \pm 3.2$ & $40.9 \pm 2.9$ \\
\hline $\begin{array}{l}\text { Serum aspartate transaminase } \\
\quad(17-40 \mathrm{IU} / 1)\end{array}$ & $20.9 \pm 5.1$ & $52.5 \pm 19.7$ & $106.7 \pm 50.3$ \\
\hline $\begin{array}{l}\text { Serum glutamyl transpeptidase } \\
(50-85 \mathrm{IU} / \mathrm{l})\end{array}$ & $18.4 \pm 7.1$ & $43.4 \pm 50.3$ & $103.5 \pm 71.2$ \\
\hline
\end{tabular}




\section{Discussion}

The results of this study show that impaired glucose tolerance and frank diabetes frequently develop in thalassaemia major despite long term iron chelation therapy with subcutaneous desferrioxamine.

A positive correlation occurred between the glucose area after chelation therapy and serum ferritin levels. In addition the patients with the highest serum ferritin levels, before subcutaneous chelation therapy, most frequently developed abnormal glucose tolerance. This chronic iron overload is clearly the cause of islet cell damage. Although an appreciable reduction in serum ferritin levels occurred with the subcutaneous chelation none of the patients achieved a normal serum ferritin level. These results show that an even more intensive chelation therapy is necessary to prevent tissue damage.

The results here suggest, however, that the diabetes is not due simply to iron deposition. Proietto et al. (1984) showed that the abnormality in carbohydrate metabolism ranges from mild glucose intolerance in $30 \%$ to $79 \%$ to frank diabetes in $12 \%$ to $17 \%$ of patients with cirrhosis not due to iron overload. The results here show an association between the age of patients or liver damage (chronic hepatitis or cirrhosis) and impaired glucose tolerance or frank diabetes.

The insulin response after oral glucose tolerance tests was also very different in the patients with normal liver function, chronic active hepatitis or cirrhosis.

As noted by Dandona et al. (1983) hyperinsulinaemia was observed here in patients with chronic active hepatitis. This could reflect either the result of pancreatic hypersecretion or decreased hepatic removal of insulin, since about $50 \%$ of the hormone secreted by the pancreas is broken down in the liver at a single passage (Rojdmark et al., 1978). Hypersecretion of insulin is unlikely, since Bonora et al. (1984) found that in chronic active hepatitis there is diminished insulin removal rather than insulin over production.

\section{References}

ADDISON, F.M., BEAMISH, M.R., HALES, C.N., HODGKINS, M., JACOBS, A. \& LLEWELLIN, P. (1972). An immunoradioactive assay for ferritin in serum in normal subjects and patients with iron deficiency and iron overload. Journal of Clinical Pathology, 35, 326.

BONORA, E., COSCELLI, C., ORIOLI, S., CAMBI, R., BUZZELLI, G., GENTILINI, P. \& BUTTURINI, U. (1984). Hyperinsulinaemia of chronic active hepatitis: impaired insulin removal rather than pancreatic hypersecretion. Hormone and Metabolic Research, 16, 111.
An analysis of our data in 11 patients with chronic active hepatitis revealed the same results. This was suggested by the fact that the fasting $\mathrm{C}$ peptide/insulin ratio was significantly reduced from control values (thalassaemics $8.2 \pm 4$, controls $11.2 \pm 3.5 ; P<0.05$ ).

On the other hand, three patients studied here with normal liver function tests showed impaired glucose tolerance and hyperinsulinism, similar to the findings of Niderau et al. (1984) in patients with haemochromatosis. They suggested that this was secondary to a receptor or intracellular impairment of hepatocyte function due to iron overload.

Although hyperinsulinaemia basal and after oral glucose tolerance test is a common finding in liver cirrhosis (Riggio et al., 1982) high levels of insulin were observed only in basal condition in our patients with cirrhosis. This is probably the result of a combined pancreatic $B$ cell dysfunction and decreased insulin catabolism in the liver.

In conclusion, impaired glucose tolerance, diabetes, chronic viral hepatitis and cirrhosis frequently develop in patients with thalassaemia major despite intensive iron chelation therapy. It is to be hoped that patients who start chelation therapy in infancy may not develop these complications but this remains to be studied. As liver damage caused by viral infections in the presence of iron overload clearly plays an important role in the development of diabetes, active immunization of all seronegative patients for hepatitis B virus is recommended.

\section{Acknowledgements}

We would like to thank Miss C. Barber and Mrs N. Baraldi for typing this manuscript. We would also like to thank Helen Cloke, Research Assistant, Francis Fraser Laboratories, Hammersmith Hospital for the insulin estimations, and $\mathbf{M}$. Laulicht, S.M.L.S.O., Department of Haematology, Royal Free Hospital, for the serum ferritin estimations.

CACCIARI, E., CICOGNANI, A., PIRAZZOLI, P., TASSONI, P., ZAPPULLA, F., SALARDI, S. \& BERNARDI, F. (1975). Relationship among the secretion of ACTH, Gn and cortisol during the insulin-induced hypoglycaemia test in the normal and obese child. Journal of Clinical Endocrinology, 40, 802.

COSTIN, G., KOGUT, M.D., HYMAN, C. \& ORTEGA, J.A. (1977). Carbohydrate metabolism and pancreatic islet cell function in thalassaemia major. Diabetes, 26, 230.

DANDONA, P., HUSSAIN, M.A.M., VARGHESE, Z., POLITIS, 
D., FLYNN, D.M. \& HOFFBRAND, A.V. (1983). Insulin resistance and iron overload. Annals of Clinical Biochemistry, 20, 77.

EDITORIAL (1980). Impaired glucose tolerance and diabetes. WHO criteria. British Medical Journal, 281, 1512.

FLYNN, D.M., FAIRNEY, A., JACKSON, D. \& CLAYTON, B.E. (1976). Hormonal changes in thalassaemia major. Archives of Disease in Childhood, 51, 828.

HALES, C.N. \& RANDLE, P.J. (1963). Immunoassay of insulin with insulin antibody precipitate. Biochemical Journal, 88, 137.

McINTOSH, N. (1976). Endocrinopathy in thalassaemia major. Archives of Disease in Childhood, 51, 195.

NIDERAU, C., BERGER, M., STREMHEL, W., STARKE, A., STROHMEYER, G., EBERT, R., SIEGEL, E. \& CREUTZFELDT, W. (1984). Hyperinsulinaemia in non-cirrhotic haemochromatosis: impaired hepatic insulin degradation? Diabetologica, 26, 441.

PRIETO, J., BARRY, M. \& SHERLOCK, S. (1975). Serum ferritin in patients with iron overload and with acute and chronic liver disease. Gastroenterology, 68, 525.

PROIETTO, J., NANKERVIS, A., AITKEN, P., DUDLEY, F.J., CARUSO, G. \& ALFORD, F.P. (1984). Insulin resistance in cirrhosis evidence for a post receptor defect. Clinical Endocrinology, 21, 677.

RIGGIO, O., MERLI, M., CANGIANO, C., CAPOCACCIA, R., CASCINO, A., LALA, A., LEONETTI, F., MAUCERI, M., PEPE, M., ROSSI FANELLI, F., SAVIOLI, M., TAMBURRANO, G. \& CAPOCACCIA, L. (1982). Glucose intolerance in liver cirrhosis. Metabolism, 31, 627.

ROJDMARK, S., BLOOM, S.G., CHOU, M.C.Y. \& FIELD, J.B. (1978). Hepatic extraction of exogenous insulin and glucagen in the dog. Endocrinologv, 102, 806.

SAUDEK, C.D., HEMM, R.M. \& PETERSON, C.M. (1977). Abnormal glucose tolerance in $\beta$-thalassaemia major. Metabolism, 26, 43.

ZUPPINGER, K., MOLINARI, B. \& HINT, A. 1979). Increased risk of diabetes mellitus in $\beta$-thalassaemia major due to iron overload. Helvetica paediatrica acta, 34, 197. 